\section{James Prescott Joule and the Unit of Energy}

Althorgh it appears from earlier letters ${ }^{1}$ that no definite agreement can be reached about the pronunciation of 'Joule', the following points may be of interest concerning a possible origin of the name and of its different pronunciations. According to A. Schuster and A. E. Shipley : 'Joule's name appears to be derived from 'Youlgrave', a village in Derbyshire where his family originally resided". It would, perhaps, be more correct to say that both 'Joule' and 'Youlgrave' had a common origin, the former in the English or Scandinavian personal name 'Tola', the place-name then meaning 'Iola's grove'. A. Mawer and F. M. Stenton ${ }^{3}$ give this meaning, though E. Ekwall' suggests instead, 'yellow grove'.

Various early forms of the place-name have been noted ; for example, 'Yolegrave' (1259) and 'Jolgreve' (fourteenth century), and there are many more recent forms. Indeed, the Rev. P. Hadfield, vicar of Youlgreave, has kindly informed me that he believes there are about forty different spellings to be found in the registers and old churchwardens' accounts, a fow examples being 'Yolgreave', 'Yolegrave', 'Yoolgrave' and 'Yoolegrave'. These forms seem to indicate variations in pronunciation. At present 'Youlgreave' is pronounced as in 'pool' and 'grave', though the inhabitants who speak the dialect pronounce it 'Yolgrav', as in 'doll' and 'have'-this on the authority of $\mathrm{Mr}$. Hadfield. He states, further, that between 1750 and 1790 , the name 'Joule' is found frequently in the registers always with that spelling. He does not say whether he has carried his investigations back to an earlier date. The Joule family had a mill at Alport in Youlgreave parish, and about twelve years ago a person named Joule visited Youlgreave; he claimed to be a descendant of the original family and was writing a book thereon.

Finally, Mr. Hadfield gives the pronunciation of the personal name as 'Jole', but himself thinks there is, no direct connexion between the names 'Joule' and 'Youlgreave'.

Chemistry Department,

K. R. WEBB.

University College, Southampton.

- NATURE, 152, 354, 418, 479 (1943).

2 Schuster, A., and Shipley, A. E., "Britain's Heritage of Science" (second edit., 1920), 40 .

"Mawer, A., and Stenton, F. M., "Introduction to the Survey of English Place-Names" (1924), 104. - Ekwall, E., "The Concise Oxford Dictionary of English Place-
Names" (1936).

If the desire is to pronounce the name as it was pronounced by the family and by the friends of Dr. Joule, there can be no doubt it is 'Joole', so as to rhyme with cool, tool or rule. Professors of the University of Manchester, in the 'eighties of last century, such as (Sir) Henry Roscoe, Balfour Stewart, (Sir) Arthur Schuster and Osborne Reynolds, all friends and some close friends of Dr. Joule, all pronounced his name in this way. Forty years ago, when as chairman of a committee for erecting a memorial to Dr. Joule in Sale Park, I met his son, Mr. B. A. Joule, he told me 'Joole' was the right pronunciation, and that in old family deeds the name was written 'Youle', like the name of the village
Youlgreave in Derbyshire in which the family lived. It would be interesting if the upholders of the pronunciation 'Jowl' would cite their authorities.

It may be worth recording the opinions of $\mathrm{Mr}$. Joule as to the published photographs of his father. The beardless face at forty-five years of age in the engraving in the memoir by Prof. Reynolds he thought too long, while the bearded face published by NatuRE and reproduced in vol. I of Joule's "Scientific Papers" he thought good. A still later photograph by Lady Roscoe, said by Reynolds to be "particularly good", is reproduced in Sir Henry Roscoe's "Life and Experiences" (Macmillan, 1906).

C. H. LeEs.

Greenacres,

Tonbridge.

Nov. 3.

THE workers in physics and engineering, respectively, in the University of Edinburgh, who were contemporary with Joule, were Tait and Fleeming Jenkin. Tait was a perfervid supporter of correct pronunciation of proper names: witness his joke regarding his fellow pupil at the Edinburgh Academy, Tate, afterwards archbishop, as a man who did not know how to spell his own name.

In the course of a prized twenty-year fellowship with Tait, wherein Joule and his work were referred to with at least annual frequency, the pronunciation I heard Tait use was invariably that which rhymed with 'pool' or 'cool'. There can be no doubt that this was Joule's own, I feel sure.

The testimony of relatives of Fleeming Jenkin would be of much value.

The Weisha,

Ninewells,

Dundee.

W. Peddie.

\section{"Timbers of the New World"}

IN his review of Record and Hess's "Timbers of the New World" Mr. Alexander L. Howard devotes half of a long paragraph to a mild reproof of the authors for saying something which actually they never said. He writes: "The authors state 'Swietenia [is] the source of the only and true mahogany', which pronouncement may be correct, and also may not". The text (p. 366) reads : "Swietenia, the source of the original or true mahogany".

There is enough evidence produced (p. 369) that the name mahogany was originally (1671) and still is applied to a tree which since 1760 has been known to science as Swietenia. The expression "original or true" was meant to convey the meaning that "true" mahogany is the kind to which the name mahogany was first applied, just as the orginal or true cedar is Cedrus. Thus it is only through misquotation that a mere statement of fact opens "a very controversial subject". The senior author has publicly expressed his opinion on this subject, but not in "Timbers of the New World".

Yale University,

SAMUEL J. RECORD.

School of Forestry,

New Haven, Connecticut. Aug. 30.

1 NATURE, 152, 144 (1943). 